Estudios de

lingüistica inglesa aplicada

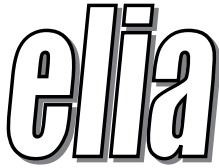

\title{
SPEECH FLUENCY IN PHRASES: TEACHING ENGLISH ORAL FLUENCY IN DISTANCE LEARNING.
}

\section{LA FLUIDEZ ORAL EN LAS LOCUCIONES: LA ENSEÑANZA DE LA FLUIDEZ ORAL EN INGLÉS EN CONTEXTOS DE APRENDIZAJE A DISTANCIA.}

\section{Inmaculada Senra Silva}

Universidad Nacional de Educación a Distancia (UNED), Spain isenra@flog.uned.es

DOI: http://dx.doi.org/10.12795/elia.2017.i17.09

The aim of the present article is to highlight the role of fluency for communication and defend the attention that it should be given within the foreign language classroom. The article presents a study on material designed as part of a project from the European Union Lifelong Learning Programme (Conversational Fluency in Phrases: Fluency for Conversational Interaction (FluenCi) 505023-LLP-1-2009-1-IEKA2-KA2MP) led by a team of researchers from the Dublin Institute of Technology (DIT), and the UNED (Universidad Nacional de Educación a Distancia). The main objective of the project was to address English language learners 'problems with perceiving and producing high-frequency phrases of spoken language which increase fluency.

Key words: fluency, L2 teaching, chunks, formulaic sequences, highfrequency phrases 
El objetivo de este artículo es destacar el papel que la fluidez tiene para la comunicación asi como defender la atención que se le debería prestar en la clase de lengua extranjera. Este artículo presenta un estudio sobre materiales que se diseñó a partir de un proyecto dentro del programa de Lifelong Learning de la Unión Europea (Conversational Fluency in Phrases: Fluency for Conversational Interaction (FluenCi) 505023-LLP1-2009-1-IE-KA2-KA2MP) dirigido por un equipo de investigadores del Dublin Institute of Technology (DIT) y la UNED (Universidad Nacional de Educación a Distancia). El objetivo principal de dicho proyecto fue analizar los problemas que los aprendices de inglés encuentran a la hora de percibir y producir expresiones de alta frecuencia del inglés oral que aumentan la fluidez.

Palabras clave: Aluidez, enseñanza de L2, secuencias formulaicas, locuciones

\section{Introduction: fluency and high-frequent phrases}

One of the most difficult challenges in teaching an L2 is finding ways to help students improve their oral fluency understood as "the rapid, smooth, accurate, lucid, and efficient translation of thought or communcative intention into language under the temporal constraints of on-line processing" (Lennon 2000: 26). Learners feel the need to speak fluently for many reasons, among them their willingness to feel confident when talking to others.

Accoding to the Common European Framwork of Reference for Languages (CEFR), a good deal of mother tongue education is devoted to building discourse skills: "In learning a foreign language, a learner is likely to start with short turns, usually of single sentence length. At higher levels of proficiency, the development of discourse competence, [...], becomes of increasing importance." (p. 123).

ELIA 17, 2017, pp. 209-232～DOI:http://dx.doi.org/10.12795/elia.2017.i17.09 
The CEFR includes, among others, a scale for spoken fluency:

\begin{tabular}{|c|c|}
\hline & CY \\
\hline $\mathrm{C2}$ & $\begin{array}{l}\text { Can express him/herself at length with a natural, effortless, } \\
\text { unhesitating flow. Pauses only to reflect on precisely the right } \\
\text { words to express his/her thoughts or to find an appropriate } \\
\text { example or explanation. }\end{array}$ \\
\hline C1 & $\begin{array}{l}\text { Can express him/herself fluently and spontaneously, almost } \\
\text { effortlessly. Only a conceptually difficult subject can hinder a } \\
\text { natural, smooth flow of language. }\end{array}$ \\
\hline \multirow[t]{2}{*}{ B2 } & $\begin{array}{l}\text { Can communicate spontaneously, often showing remarkable } \\
\text { fluency and ease of expression in even longer complex stretches } \\
\text { of speech. }\end{array}$ \\
\hline & $\begin{array}{l}\text { Can produce stretches of language with a fairly even tempo; } \\
\text { although he/she can be hesitant as he/she searches for patterns } \\
\text { and expressions, there are few noticeably long pauses. Can interact } \\
\text { with a degree of fluency and spontaneity that makes regular } \\
\text { interaction with native speakers quite possible without imposing } \\
\text { strain on either party. }\end{array}$ \\
\hline \multirow[t]{2}{*}{ B1 } & $\begin{array}{l}\text { lative ease. Despite some problems } \\
\text { oauses and 'cul-de-sacs', he/she is } \\
\text { jithout help. }\end{array}$ \\
\hline & $\begin{array}{l}\text { Can keep going comprehensibly, even though pausing for } \\
\text { grammatical and lexical planning and repair is very evident, } \\
\text { especially in longer stretches of free production. }\end{array}$ \\
\hline \multirow[t]{2}{*}{$\mathrm{A} 2$} & $\begin{array}{l}\text { Can make him/herself underst } \\
\text { though pauses, false starts and }\end{array}$ \\
\hline & $\begin{array}{l}\text { Can construct phrases on familiar topics with sufficient ease to } \\
\text { handle short exchanges, despite very noticeable hesitation and } \\
\text { false starts. }\end{array}$ \\
\hline A1 & $\begin{array}{l}\text { Can manage very short, isolated, mainly pre-packaged utterances, } \\
\text { with much pausing to search for expressions, to articulate less }\end{array}$ \\
\hline
\end{tabular}

Fig.1. CEFR scale for spoken fluency (p. 129). 
Proficiency in English or any other language is not simply the correct use of vocabulary and grammar, but also the capacity to interact in social communication which entails that learners need to use hundreds of items of prefabricated language each with its characteristic intonation patterns. Language is made up not only of individual words but also of formulaic language. Until the 90's experts on language learning claimed that formulaic language was outside the creative language process (e.g. Krashen \& Scarcella, 1978). However, a few years later, Ellis (1996) argued that language acquisition was essentially sequence learning. In a later publication (2012) he contended that language learners with better sequencing ability in phonological short-term memory (PSTM) were more successful in acquiring vocabulary and grammar, and he proposed what he called 'chunking' as a process of SLA. He defended the idea that extensive exposure to formulaic sequences increases fluency of speech production. Various studies have been carried out in this sense, as Taguchi (2007), Wood (2008), Khodadady and Shamsaee (2012).

In his article, Peters (1983: 40-41) proposed six tasks that learners must perform in learning a language:

1. Extracting and remembering chunks from inputs they receive.

2. Comparing those recently learned chunks with those which had been learnt previously.

3. Connecting them with familiar and similar chunks in various ways including pragmatic connection, semantic connection, phonological connection, and syntactic connection.

4. Unpacking the chunks into some known subparts.

5. Storing some of those encountered chunks in the lexicon repertoire and discarding those which may seem less useful.

6. Trying and revising them in later stages.

Martinez and Schmitt (2012) highlight the importance of formulaic sequences, and the need to be addressed in teaching pedagogy. These 
authors explain that "individual formulaic sequences behave much the same as individual words, matching a single meaning or function to a form, although that form consists of multiple orthographic or phonological words" (2012: 299). Martinez and Schmitt (2012) review the reasons why formulaic sequences are so essential in language. First, formulaic sequences are widespread in language use. A number of studies have shown that a large amount of discourse is made up of different kinds of these sequences. Second, meanings and functions are often realized by formulaic sequences. Third, formulaic language has processing advantages. There is now ample evidence to show that formulaic sequences are processed faster and more accurately than creatively generated language (Conklin and Schmitt, 2008). Fourth, formulaic language can improve the overall impression of L2 learners' language production.

In the last years formulaic language has gone from being peripheral in language teaching to becoming fundamental to the way language is acquired, processed and used (Martinez and Schmitt, 2012). At present there is general consensus on the importance of formulae in L1, L2 and FL acquisition and learning. Some scholars such as Wray (2009) and Peters (2009) believe that learning and acquiring language starts from whole and then moves to breaking down this whole into its comprising components (Khodadady and Shamsaee, 2012: 40).

Formulaic language promotes efficient and effective communication and can improve the overall impression of L2 learners' language production. As noted by Ellis and Sinclair (1996: 234), '[t]he attainment of fluency, in both native and foreign languages, involves the acquisition of memorized sequences of language'. Boers et al. (2006), for example, showed that L2 speakers were judged as more proficient when they used formulaic sequences.

Analysis of spoken corpora (the spoken component of the British National Corpus, Cancode, and the Dynamic Speech Corpus) shows the importance of high-frequency phrases in informal L1-L1 speech since these chunks of spoken English are extremely frequent. A characteristic of native dialogue is that a large percentage of informal speech is prefabricated (Wang 2010), and the absence or incorrect intonation of these formulaic sequences mark speakers as outsiders.

ELIA 17, 2017, pp. 209-232ＤOI:http://dx.doi.org/10.12795/elia.2017.i17.09 
The most frequent phrases in oral language are very frequent indeed, they make up a very high proportion of what native speakers say, and they perform vital functions in conversational interaction; to a very considerable extent, being good at speaking the language means being good at using these phrases. Yet they have never featured in any principled, comprehensive way in language teaching materials. Neither have prosody, intonation or formulaicity.

For many years the European Union has been working on a comprehensive migration policy and has given special importance to the role of language skills in integration. There is a growing awareness in the European Union that immigrant citizens who do not speak the language of the society in which they live have restricted access to the labour market because of inadequate language skills, and they cannot function as full members of their host communities. Integration requires familiarization with native-to-native spoken language, both for reception and production. A way of helping speakers of other languages to integrate into an English speaking community is providing them with tools to achieve fluency in their speech.

As for language learners in general, there is considerable evidence that students of a language who use such frequent phrases naturally are more likely to integrate successfully in environments where that language is the mother tongue. They will be at a disadvantage if they cannot understand and use these phrases in spontaneous conversation.

Despite the importance of communication interaction, the teaching and learning of conversational English suffers because the materials available do not contain the many hundreds of phrases that people who speak the language fluently employ. In this sense, language learners do not have adequate exposure to unscripted, natural dialogue and the way native speakers cooperate to construct meaning in real communicative situations. It is clear that fluency-enhancing strategies are needed. Besides, given the importance of formulaic language and high-frequency phrases, it can be argued that they need to be part of language syllabuses. Moreover, it should naturally have a prominent place in language teaching textbooks and materials, as well as tests of language achievement and proficiency. 
Unfortunately, this is generally not the case. A perusal of almost any EFL/ ESL textbook or test yields a paucity of formulaic sequences targeted for explicit attention/noticing, and even for those that do occur, there does not seem to be much principled basis for selection (Koprowski 2005; Gouverneur 2008; Hsu 2008).

\section{FluenCi}

FluenCi was a 30-month project whose main objective was to address the English language learners' problems with processing and producing elements of spoken speech which increase fluency, such as the use of highfrequency chunks, intonation and emphatic patterns. The project was based around a set of approximately 200 high-frequency phrases (called the PHRASEeCON), and was built on research by the members of the projet and scholars such as McCarthy and Carter (2002).

Foreign language students must get prepared for real language, real native-to-native dialogue because the language people have to confront in real life is very different to the one presented in traditional classroom settings and textbooks. In real communication people hesitate, reformulate, and are iterrupted by the other speaker/s. Besides, they do not construct their speech one word at a time; they use hundreds of phrases such as if you see what I mean and at the end of the day and this that and the other. These phrases also perform some discourse functions such as saving face and being polite; indicate vagueness, approximation and hesitancy. The CEFR includes some aspects of discourse competence such as flexibility to circumstances, turntaking, thematic development, and coherence and cohesion:

\begin{tabular}{|l|l|}
\hline & FLEXIBILITY \\
\hline C2 & $\begin{array}{l}\text { Shows great flexibility reformulating ideas in differing linguistic } \\
\text { forms to give emphasis, to differentiate according to the situation, } \\
\text { interlocutor, etc. and to eliminate ambiguity. }\end{array}$ \\
\hline C1 & As B2+ \\
\hline
\end{tabular}

ELIA 17, 2017, pp. 209-232ＤOI:http://dx.doi.org/10.12795/elia.2017.i17.09 


\begin{tabular}{|l|l|}
\hline B2 & $\begin{array}{l}\text { Can adjust what he/she says and the means of expressing it } \\
\text { to the situation and the recipient and adopt a level of formality } \\
\text { appropriate to the circumstances. }\end{array}$ \\
\cline { 2 - 3 } & $\begin{array}{l}\text { Can adjust to the changes of direction, style and emphasis normally } \\
\text { found in conversation. Can vary formulation of what he/she wants } \\
\text { to say. }\end{array}$ \\
\hline B1 & $\begin{array}{l}\text { Can adapt his/her expression to deal with less routine, even } \\
\text { difficult, situations. }\end{array}$ \\
\cline { 2 - 3 } & $\begin{array}{l}\text { Can exploit a wide range of simple language flexibly to express } \\
\text { much of what he/she wants. }\end{array}$ \\
\hline A2 & $\begin{array}{l}\text { Can adapt well rehearsed memorised simple phrases to particular } \\
\text { circumstances through limited lexical substitution. }\end{array}$ \\
\cline { 2 - 3 } & $\begin{array}{l}\text { Can expand learned phrases through simple recombinations of } \\
\text { their elements }\end{array}$ \\
\hline A1 & No descriptor available. \\
\hline
\end{tabular}

Fig.2. CEFR scale for flexibility (p. 124).

Finding out which are the most frequent phrases in English and how they are used is not an easy task. If a scientific approach were followed then a multi-million word corpus of spoken English should be built and analyzed. Using corpora is overwhelmingly preferable to relying on native speaker introspection. Besides it enables us to determine an order of frequency and so prioritise the most frequent phrases in our teaching materials. Furthermore it allows us to study a large number of authentic examples of each phrase in use. However, building a representative corpus of spoken English is very expensive, labour-intensive and time-consuming.

Corpora of spoken English tend to be much smaller than corpora of written English and therefore more prone to quantitative bias. In order to choose the most frequent phrases in English, it was decided therefore to compare the frequency list generated from the British National Corpus with 
an equivalent list from the five-million-word Cancode Corpus provided by Cambridge University Press. Only phrases that both corpora suggested were deserving were included, and researchers were also guided by other pedagogical considerations such as difficulty and range of use.

A manual analysis to separate different senses of an identical form followed: it was necessary to establish, for example, if come on in the sense of Come on! We're late is more frequent than in the sense We can't come on Monday. A list of 200 frequently occurring key phrases was generated. The first words in the list were:

1. you know

2. I think (that)

3. a bit

4. (always, never) used to +inf

5. as well

6. (no.) pounds

7. thank you

8. (no.) years

9. in fact

10. very much
11. talking about sth.

12. I suppose

13. this morning

14. (not) any more

15. come on (Int.)

16. number (no.)

17. come back

18. last year

19. so much

20. this year

The next step was to design innovative learning materials to make learners aware of language processing and improve their oral fluency, something which has hitherto been a neglected area in foreign language learning. These teaching materials would combine recent developments of corpus linguistics, ample experience in teaching languages and an innovative application of slow-down technology designed by colleagues at DIT which gives the learners more time to appreciate the intonation patterns of native-speech production without tonal distortion. These chunks 
are usually delivered at high speed and in single tone unit so it is not easy to teach how they are used and pronounced. The slow-down technology allows recorded speech to be played back at a slower speed without tonal distortion, which helps students to notice and reproduce features that are not always easy to hear clearly in natural conversation.

The materials that have been developed as part of the project aim to facilitate the learner acquiring and improving the skills of using and pronouncing these high-frequent phrases. The materials are self-contained and capable of independent use and are extremely good for students with no access to traditional classroom settings.

The materials consist of 20 dialogues (of approximately 400-500 words each) where the 200 phrases are embedded in carefully prepared 'natural settings'. Then exercises are drafted in such a way that the materials can be studied in approximately twenty-five hours (1 ECTS credit). The time constraints are set so as to comply with the requirements of the Bologna Agreement. Students need to spend time learning grammar and vocabulary and developing their reading and writing skills apart from their listening and speaking skills. Time is perhaps the student's most precious resource. It was therefore essential to make the materials as time efficient as possible. Materials were made as simple and user-friendly as possible. Each of the 20 dialogues is exploited in the same way so that there is a 'positive transfer' from unit to unit. Users quickly know what to expect and can concentrate on the new language rather than on the mechanics of the exercises.

\section{Materials}

The materials designed as a result of the FluenCi project can be accessed online. Students are introduced to the materials which consist of dialogues or lessons where a number of frequent phrases are used and explained. In order to complete the units, students must follow the instructions and read/ watch the introductory text and video to each dialogue. Later they can navigate to the frequent phrases for that specific dialogue. 


\section{Introduction}

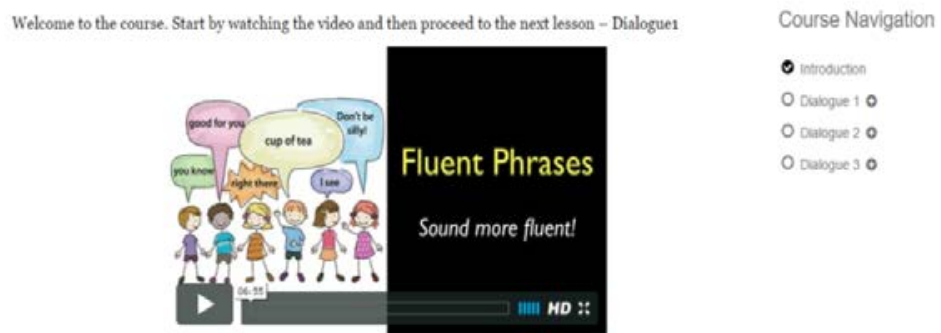

Fig.3. Introductory video to FluenCi materials.

Each dialogue includes a number of high-frequency phrases to be studied by the students. First students watch a video and can listen to a dialogue where the phrases which are going to be studied in the unit have been embedded. In dialogue one, for example, phrases such as cup of tea, right there, 'good for you, you know, you know what I mean, I see, are studied.

\section{Dialogue 1}

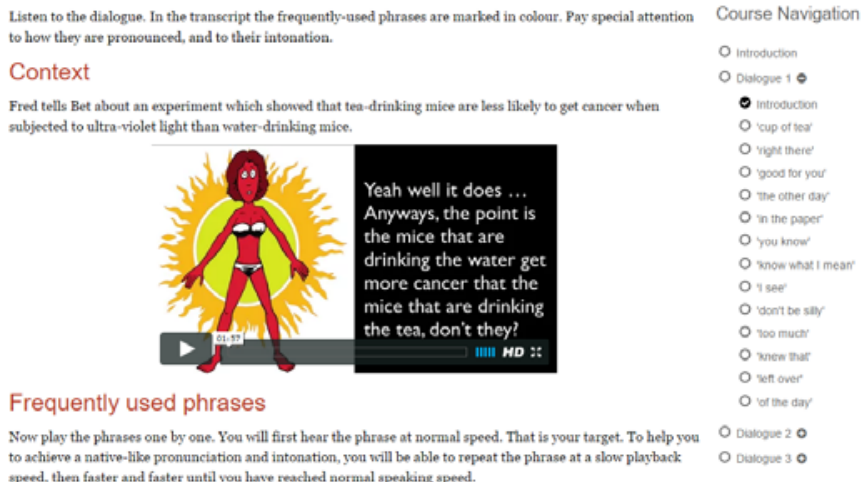

Fig.4. Introductory video to dialogue 1.

ELIA 17, 2017, pp. 209-232～DOI:http://dx.doi.org/10.12795/elia.2017.i17.09 
Then students can listen to each of the phrases inserted in a sentence at normal speed. Students are explained how to use each of the phrases.

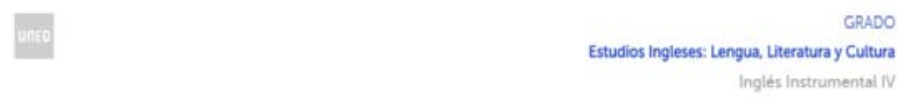

Introduction

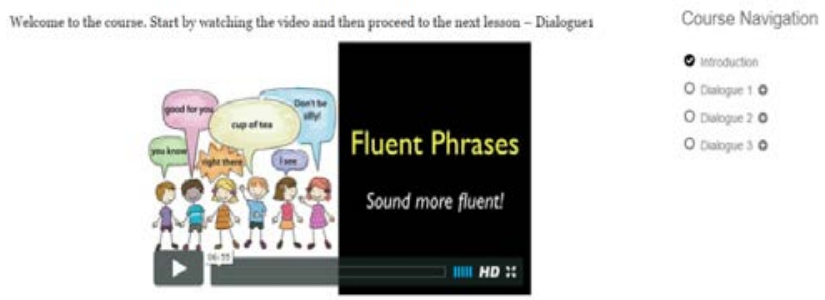

Fig.5. Explanatory video on the use of 'cup of tea'.

Once students understand the dialogues, they can listen to each phrase slowed down to $40 \%, 60 \%$ and $80 \%$ speed thanks to the slow-down technology designed by DIT. This slow-down facility allows them to study the intonation patterns which characterise the way these phrases are uttered.

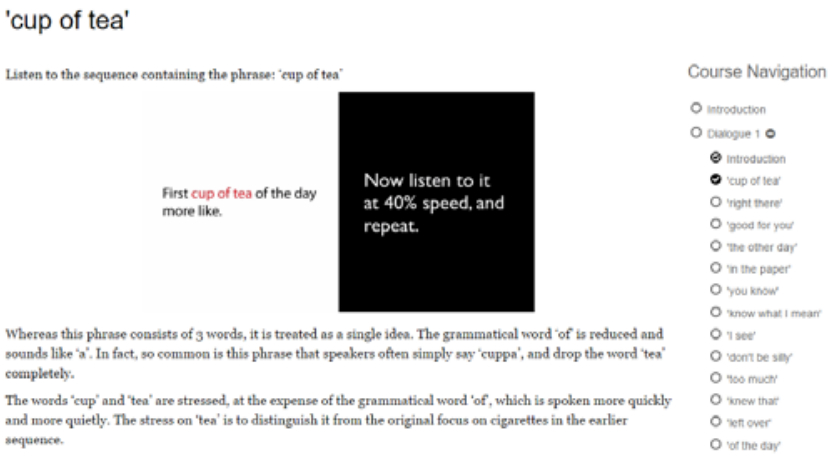

Fig. 6. Use of the slow-down technology with 'cup of tea' ( $40 \%$ speed).

ELIA 17, 2017, pp. 209-232ＤOI:http://dx.doi.org/10.12795/elia.2017.i17.09 
'cup of tea'

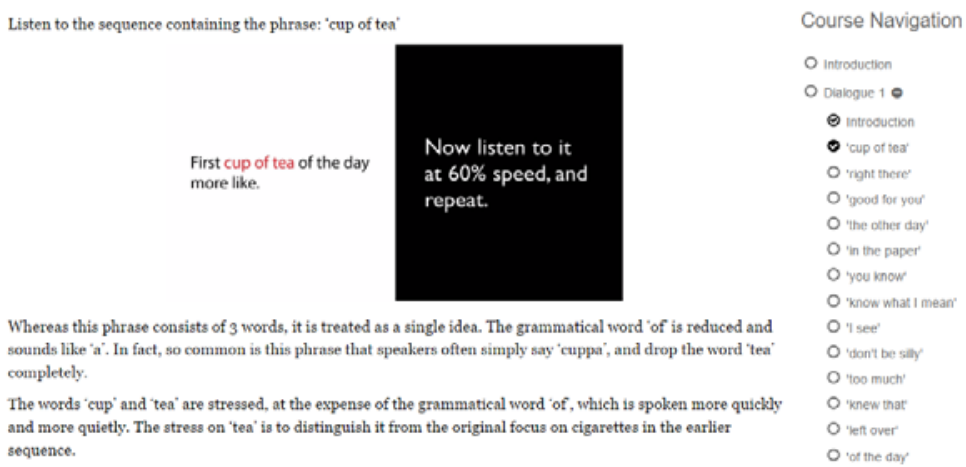

Fig.7. Use of the slow-down technology with 'cup of tea' (60\% speed).

'cup of tea'

\begin{tabular}{|c|c|c|}
\hline \multicolumn{2}{|l|}{ Listea to the sequence containing the phrase: 'cup of tea' } & Course Navigation \\
\hline $\begin{array}{l}\text { First cup of tea of the day } \\
\text { more like. }\end{array}$ & $\begin{array}{l}\text { Now listen to it } \\
\text { at } 80 \% \text { speed, and } \\
\text { repeat. }\end{array}$ & 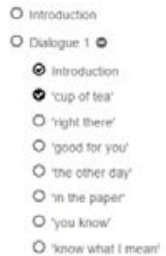 \\
\hline $\begin{array}{l}\text { Whereas this phrase consists of } 3 \text { words, it is treated a } \\
\text { sounds like 'a'. In fact, so common is this phrase that } \\
\text { completely. }\end{array}$ & $\begin{array}{l}\text { ingle idea. The grammatical word 'of is reduced and } \\
\text { sers often simply say 'cuppa', and drop the word tea' }\end{array}$ & $\begin{array}{l}\text { O y ser } \\
0 \text { vont be saly } \\
0 \text { roo much }\end{array}$ \\
\hline $\begin{array}{l}\text { The words 'cup' and 'tea' are stressed, at the expense o } \\
\text { and more quietly. The stress on 'tea' is to distinguish it } \\
\text { seqgence. }\end{array}$ & $\begin{array}{l}\text { grammatical word of, which is spoken more quickly } \\
\text { nt the original focus on cigarettes in the earlier }\end{array}$ & $\begin{array}{l}\text { O vnew thar } \\
\text { O vet over } \\
\text { O of the day }\end{array}$ \\
\hline
\end{tabular}

Fig.8. Use of the slow-down technology with 'cup of tea' ( $80 \%$ speed).

\section{Study}

In order to test the materials, check if they are useful for students and find ways to improve them, a pilot study was carried out by one of the partners, namely the UNED. The target group were UNED students (mostly

ELIA 17, 2017, pp. 209-232ＤOI:http://dx.doi.org/10.12795/elia.2017.i17.09 
Spanish) who could access the learning materials online through the UNED aLF virtual platform. Data were collected from 24 UNED students enrolled in Inglés Instrumental IV, a one-semester course which takes students from level B2- to B2+. Students participated on a voluntary basis. UNED students are long-distance learning students who need materials to improve their listening and speaking skills. The UNED virtual courses are embedded in a platform, aLF, where the FluenCi materials were uploaded together with a brief introduction on what they were and how to use them.

Informants answered a Google pre-test questionnaire (see appendix I) whose main objective was to check the time spent by each student learning English, years of exposure to the language, and resources they employ to improve their listening and speaking skills.

Informants were aged 22-52. The numbers of years they had been studying English ranged from 2 to 18 . Furthermore, most students never used the language outside the language classroom. Most informants explained that they use internet to access dictionaries, movies, listen to music or watch films, in order to improve their listening skills. Most students added that they employed from 5 to 10 hours a week to improve their listening skills, whereas one informant said he did not spend any time improving his listening skills. To the question of how they thought they could improve their listening skills, most students answered that they did so by listening to radio and TV programmes, meeting native speakers, practicing more in class, and listening to native speakers.

Once they finished the pre-test questionnaire, they were asked to go to the materials and study them. Then, they were requested to fill in a posttest questionnaire (see appendix II).

Most students explained that the phrases that were new to them or with nuances that were unknown to them previous to the study of the materials were sort of thing, left over and mind you. As for phrases that they already knew but for which they found other uses after completing the units, they highlighted sort of thing and I reckon. 54,4\% of the informants answered that the introductory video on the materials was useful. $54,4 \%$ found themselves comfortable at $80 \%$ speed. Finally, $36,4 \%$ felt $100 \%$ 
speed helped them understand intonation better, whereas another $36,4 \%$ felt $80 \%$ was better.

As for the question on what they liked most about the materials, $45,5 \%$ answered that they focused on a skill they had never worked on before, whereas $45,5 \%$ replied that they liked the fact that they could work at their own pace, and 9,1\% the fact that the materials were innovative.

In relation to the question of what they would like future materials to include, the answers were (1) more practice, (2) an app to record and listen to themselves, and which could tell them if they pronounce correctly, (3) an app to repeat and learn from their mistakes, (4) varieties of English, (5) more units, (6) more examples, (7) more oral English expressions that are less common than the ones used in these units.

As for the difficulty of the materials, $36,4 \%$ answered that they found them a bit difficult, whereas $54,5 \%$ didn't find them difficult at all. Students were also asked if the materials had helped them improve their oral fluency. In this respect, 27,3\% found they hadn't helped them much, $36,4 \%$ believed they had helped them sufficiently, and $27,3 \%$ thought they had helped them enough.

The final question was related to intonation. $36,4 \%$ found the materials had helped them enough, $36,4 \%$ sufficiently, and $18,2 \%$ little.

Most students highlighted the fact that these materials were different to what they normally find in textbooks and visually attractive for learners, which encouraged us to design more units.

\section{Conclusions}

In this article we have highlighted the importance of fluency for oral communication and the need to design and include more teaching materials that teach and reinforce this skill. As part of the FluenCi project materials to teach high-frequency phrases were designed, and a study was carried out to check their effectivity. Students found them useful and requested further material and practice. Our objective now is to design further units and improve the interface.

ELIA 17, 2017, pp. 209-232～DOI:http://dx.doi.org/10.12795/elia.2017.i17.09 


\section{References}

Alali, F. A. \& Schmitt N. (2012). Teaching Formulaic Sequences: The Same asor Different From Teaching Single Words? TESOL Journal, 3.2, 153-180. https://doi.org/10.1002/tesj.13

Aronsson, B. (2014). "Prosody in the foreign language classroom - Always present, rarely practised? Journal of Linguistics and Language Teaching, $5 / 2,207-224$.

Boers, F., et al. (2006). Formulaic sequences and perceived oral proficiency: putting a Lexical Approach to the test. Language Teaching Research, 10/3, 245-261. https://doi.org/10.1191/1362168806lr195oa

Conklin, K. \& Schmitt N. (2008). Formulaic sequences: Are they processed more quickly than nonformulaic language by native and nonnative speakers? Applied Linguistics, 29/1, 72-89. https://doi.org/10.1093/applin/amm022

Derwing, T. M. et al. (2004). Second language fluency: Judgements on different tasks. Language Learning, 54:4, 655-679. https://doi.org/10.1111/j.14679922.2004.00282.x

Ellis, N. C. (2012). Formulaic Language and Second Language Acquisition: Zipf and the Phrasal Teddy Bear. Annual Review of Applied Linguistics 32, 1744. https://doi.org/10.1017/S0267190512000025

Ellis, N. C. \& Sinclair, S. G. (1996). Working memory in the acquisition of vocabulary and syntax: putting language in good order. The Quarterly Journal of Experimental Psychology 49/1, 234-250. https://doi. org/10.1080/027249896392883

Gouverneur, C. (2008). The phraseological patterns of high-frequency verbs in advanced English for general purposes: a corpus-drived approach to EFL textbook analysis. In F. Meunier \& S. Granger (Eds.), Phraseology in Foreign Language Learning and Teaching (pp. 223-243). Amsterdam: John Benjamins. https://doi.org/10.1075/z.138.17gou

Hsu, J. T. (2008). Role of the multiword lexical units in currect EFL/ESL textbooks. US-China Foreign Language, 6, 27-39.

Khodadady, E. \& S. Shamsaee (2012). Formulaic Sequences and Their Relationship

ELIA 17, 2017, pp. 209-232ＤOI:http://dx.doi.org/10.12795/elia.2017.i17.09 
with Speaking and Listening Abilities. English Language Teaching, 2, 3949. https://doi.org/10.5539/elt.v5n2p39

Koprowski, M. (2005). Investigating the usefulness of lexical phrases in contemporary coursebooks. ELT Journal 59/4, 322-332. https://doi. org/10.1093/elt/cci061

Lennon, P. (1990). Investigating fluency in EFL: A quantitative approach. Language Learning, 3, 387-417. https://doi.org/10.1111/j.1467-1770.1990.tb00669.x

Lennon, P. (2000). The lexical element in spoken second language fluency. In H. Riggenbach (Ed.), Perspectives on fluency (pp. 25-42). Ann Arbor, MI: University of Michigan Press.

McCarthy, M. \& R. Carter (2002). This that and the other: multi-word clusters in spoken English as visible patterns of interaction. Teanga. Yearbook of the Irish Association for Applied Linguistics, 21, 30-52.

Martinez, R. \& N. Schmitt. (2012). A phrasal expressions list. Applied Linguistics, 33/3, 299-320. https://doi.org/10.1093/applin/ams010

Peters, A. M. (2009). Connecting the dots to unpack the language. In R. Corrigan et al. (Eds.), Formulaic language: Acquisition, loss, psychological reality, and functional explanations, V. 1.2. (pp. 387-402). Philadelphia: John Benjamins. https://doi.org/10.1075/tsl.83.08pet

Schmitt, N. (Ed.) (2004) Formulaic sequences: Acquisition, processing and use. Amsterdam: John Benjamins. https://doi.org/10.1075/1llt.9

Taguchi, N. (2007). Chunk learning and the development of spoken discourse in a Japanese as a foreign language classroom. Language Teaching Research, 11, 433-457. https://doi.org/10.1177/1362168807080962

Wang, Y. (2010) Perception and Acquisition of Natural Authentic English Speech for Chinese Learners Using DIT's Speech Technologies. Doctoral Thesis, Dublin Institute of Technology. Retrieved from https://arrow.dit.ie/cgi/ viewcontent.cgi?referer $=$ https://www.google.es/\&httpsredir $=1 \&$ article $=10$ $24 \&$ context $=$ appadoc

Wray, A. (2002). Formulaic language and the lexicon. Cambridge: Cambridge University Press. https://doi.org/10.1017/CBO9780511519772

ELIA 17, 2017, pp. 209-232ＤOI:http://dx.doi.org/10.12795/elia.2017.i17.09 


\section{Appendix I}

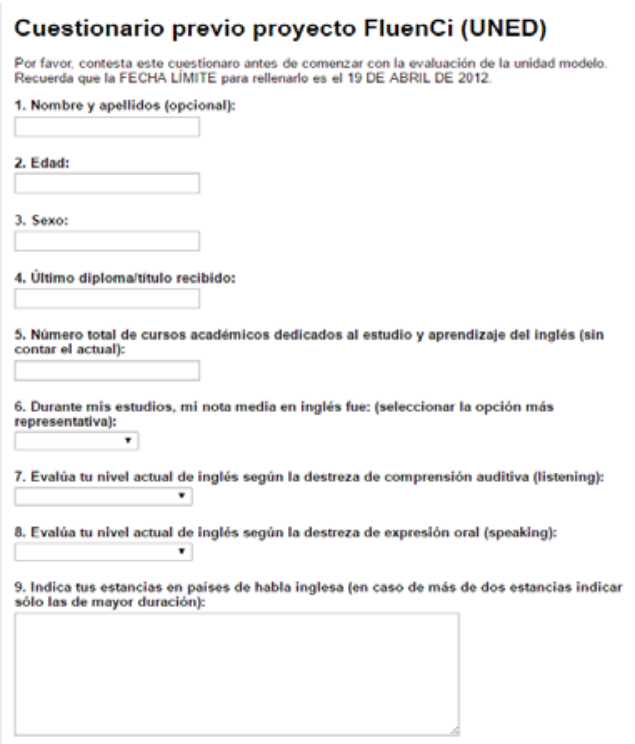

10. Indica si habitualmente utilizas la lengua inglesa fuera del ambito de los estudios (por ejemplo, con amigos, parientes, etc.)

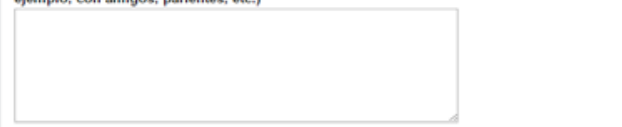

11. Indica tu nivel de conocimiento de otros idiomas modernos que conozcas:

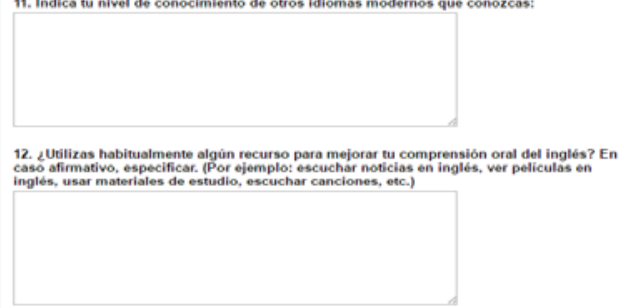

13. ¿Cuánto tiempo dedicas a la semana a mejorar tu comprensión auditiva en inglés?

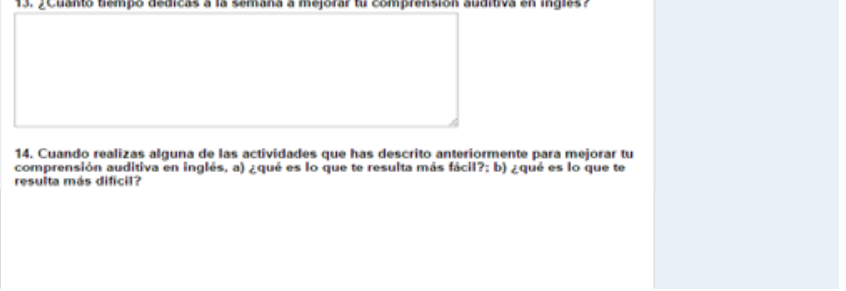

ELIA 17, 2017, pp. 209-232～DOI:http://dx.doi.org/10.12795/elia.2017.i17.09 
15. ¿Cómo crees que puedes mejorar tu comprensión auditiva en inglés?

\section{Appedix II}

Cuestionario sobre el material desarrollado por el equipo docente de Inglés Instrumental III-VI para mejorar la fluidez oral

Estimado estudiante:

El objetivo de estos materiales es que aprendas expresiones de alta frecuencia sin las cuales los diálogos en inglés suenan poco naturales. La entonación de estas expresiones - la forma en la que se dicen - también es importante.

Una vez que trabajes los materiales nos gustaría que nos proporcionaras retroalimentación/feedback para ayudarnos a mejorarlos.

\section{Información personal:}

Email:

Edad:

¿Posees algún certificado de conocimiento de inglés? En caso afirmativo, indicar el más avanzado.

¿Cómo calificarías tu nivel de inglés oral?

Básico/elemental pre-intermedio/intermedio

Intermeido/avanzado pseudo-nativo

Por favor, una vez realizado el curso responde a las siguientes preguntas. No te llevará más de un par de minutos. 
1. ¿Qué expresiones eran nuevas para ti antes de trabajar los materiales?

- cup of tea

- right there

- good for you

- the other day

- in the paper

- you know

- know what I mean

- I see

- don't be silly

- too much

- knew that

- left over

- of the day

- this year

- really good

- half of it

- last year

- a bit

- I see

- rather than

- good enough

- I reckon

- no problem

- no problems

- used to

- no way

- live in

- in fact

- half past

- decide to

- these days

- at school
- in fact

- know it

- that book

- so far

- a million pounds

- not enough

- I'm afraid

- have to

- months ago

- one million pounds

- these things

- in the morning

- over there

- you know

- these ones

- sort of thing

- I think

- these things

- get rid of

- As a matter of fact

- know it

- looks like

- I mean

- every day

- too much

- I reckon

- something else

- on top of that

- mind you

- I mean

- sit down

- One man's 
2. Después de realizar el curso, ¿qué expresiones que ya conocías has visto de otro modo/con una nueva perspectiva?

- cup of tea

- right there

- good for you

- the other day

- in the paper

- you know

- know what I mean

- I see

- don't be silly

- too much

- knew that

- left over

- of the day

- this year

- really good

- half of it

- last year

- a bit

- I see

- rather than

- good enough

- I reckon

- no problem

- no problems

- used to

- no way

- live in

- in fact

- half past

- decide to

- these days

- at school
- in fact

- know it

- that book

- so far

- a million pounds

- not enough

- I'm afraid

- have to

- months ago

- one million pounds

- these things

- in the morning

- over there

- you know

- these ones

- sort of thing

- I think

- these things

- get rid of

- As a matter of fact

- know it

- looks like

- I mean

- every day

- too much

- I reckon

- something else

- on top of that

- mind you

- I mean

- sit down

- One man's 
3. ¿Te ha parecido útil el vídeo introductorio a los materiales (Introduction)? (valora de 0-5)

Nada útil poco útil útil bastante útil muy útil

4. Con qué velocidad de reproducción te has sentido más cómodo/a?
(a) $100 \%$
(b) $80 \%$
(c) $60 \%$
(d) $40 \%$

5. Qué velocidad de reproducción te ha ayudado a entender mejor la entonación?
(a) $100 \%$
(b) $80 \%$
(c) $60 \%$
(d) $40 \%$

6. ¿Qué te ha gustado de los materiales?

7. ¿Qué no te ha gustado de los materiales?

8. ¿Qué te gustaría que incluyéramos en los materiales en futuros desarrollos?

ELIA 17, 2017, pp. 209-232 DOI:http://dx.doi.org/10.12795/elia.2017.i17.09 
9. ¿Los vídeos te han resultado difíciles para tu nivel de inglés?

1. Nada 2. Poco 3. Suficiente 4. Bastante 5. Mucho

10. ¿Has trabajado la fluidez oral con anterioridad? ¿Cómo?

11. ¿ Crees que el material proporcionado te ha servido para mejorar tu fluidez?

1. Nada 2. Poco 3. Suficiente 4. Bastante 5. Mucho

12. ¿Crees que los materiales material proporcionados te han servido para mejorar tu pronunciación?

1. Nada 2. Poco 3. Suficiente 4. Bastante 5. Mucho

13. ¿Crees que los materiales proporcionados te han servido para mejorar tu entonación?

1. Nada 2. Poco 3. Suficiente 4. Bastante 5. Mucho 
14. Como futuro/a filólogo/a, ¿qué grado de importancia consideras que tiene aprender estas expresiones frecuentes?

1. Nada 2. Poco 3. Suficiente 4. Bastante 5. Mucho

15. ¿Algún comentario adicional que quieras hacer sobre el material proporcionado?

¡Gracias por ayudarnos a mejorar este curso!

First version received: July 2017

Final version accepted: October 2017

ELIA 17, 2017, pp. 209-232ＤOI:http://dx.doi.org/10.12795/elia.2017.i17.09 